\title{
Determination of Indicator Plants for Boron in the Kırka (Eskişehir/Turkey) Boron Deposit Area
}

\author{
Zeynep Özdemir ${ }^{1 *}$, Semiha Zorlu ${ }^{2}$, Mustafa Akyıldız ${ }^{2}$, Fulya Yücesoy Eryılmaz ${ }^{1}$ \\ ${ }^{1}$ Department of Geology Engineering, Mersin University, Mersin, Turkey \\ ${ }^{2}$ Department of Geology Engineering, Çukurova University, Adana, Turkey \\ Email: “zozdemir@mersin.edu.tr, “zeyrut@gmail.com, ksemiha@hotmail.com, \\ akyildizm@cu.edu.tr, fyucesoy@mersin.edu.tr
}

Received February 22, 2013; revised March 25, 2013; accepted April 21, 2013

Copyright (C) 2014 Zeynep Özdemir et al. This is an open access article distributed under the Creative Commons Attribution License, which permits unrestricted use, distribution, and reproduction in any medium, provided the original work is properly cited. In accordance of the Creative Commons Attribution License all Copyrights (c) 2014 are reserved for SCIRP and the owner of the intellectual property Zeynep Özdemir et al. All Copyright (c) 2014 are guarded by law and by SCIRP as a guardian.

\begin{abstract}
The amount of elements in plants is important for biogeochemical explorations. Some plants which were accumulated extremely elements, are called indicator plants. In this study, the 11 plant species and soil samples were collected boron deposits area in Kurka (Eskişehir). Boron is determinated in plants (leaves and twigs) and soil samples. Additionally, statistical relations were established between the boron values of plant and soil samples and three plants were only found. The boron in twigs of Puccinellia intermedia $(\mathrm{n}=17, \mathrm{r}=\mathbf{0 . 7 2 7 4})$, twigs of $\mathrm{Ge}$ nista aucheri $(\mathrm{n}=26, \mathrm{r}=\mathbf{0 . 8 5 8 1})$ and leaves of Pinus nigra $(\mathrm{n}=16, \mathrm{r}=\mathbf{0 . 6 8 0 5})$ species are found 119,81 and 115 $\mathrm{mg} / \mathrm{kg}$ respectively. This species was reflected boron in soil and their used indicator plant for boron. The indicator plants could be successfully used for biogeochemical prospecting and environmental monitoring.
\end{abstract}

\section{KEYWORDS}

\section{Biogeochemistry; Boron; Indicator Plant; Kırka (Eskişehir/Turkey)}

\section{Introduction}

The Turkish borate deposits (Bigadiç, Sultançayırı, Kestelek, Emet and Kirka) are approximately 75\% - 85\% of the world reserves that contain some borate minerals such as coleminite, ulexite borax, etc. The Kırka (Eskişehir/ Turkey) deposit which is one of the most important borate minerals, is the largest boron deposit not only in Turkey but also in the world (Figure 1) [1,2].

In the literature, many geochemical and geophysical methods have been used to explore the new mining deposits. The resistivity and seismic methods are used in the gravity and magnetic geophysical researches, particularly for borate deposits created by sedimentary filling. On the other hand, the drilling method with geological mapping is one of the most suitable methods in order to explore the new mining deposits in the world [3,4].

Recently, the biogeochemical prospecting methods are successfully used for detection of the new mining depo-

${ }^{*}$ Corresponding author. sits. These methods include the determination elements in different organs of plants such as leaves, twigs or roots and soil. In generally, the relationship between the amount of elements in plant and soil is used for determine the indicator plants. In the literature, several indicator plants are found for $\mathrm{Au}$ and $\mathrm{Fe}, \mathrm{Mn}, \mathrm{Zn}, \mathrm{Cu}$, and other elements [4-20].

Boron is metalloid and essential for plant functions. When presented in suboptimal or in excess amount, it may become nutritional deficiency or toxic [21,22]. However, some plant species extremely accumulated or tolerated boron. It was reported that only the Eurotia ceratoides, Limonium suffruticosum and Salsola nitraria species in Russia were accumulated boron [5].

In this study, the amount of the boron is determinated in plant and soil samples in Kırka (Eskisehir-Turkey) borate deposits and investigated plant-soil relationships for each plant species organs. The indicator plant species which are found could be used as guidelines in order to determine the borate deposits and environmental moni- 
toring in future studies.

\section{Geology and Location of Borate Deposits}

There are three coeval assemblages in the west of Central Anotolia (from West to East) in the youngest Alpine magmatism (Miocene to Quaternary). They are the Western Anatolian Volcanic assemblage, the N-S trending Kirka-Afyon-Isparta Alkaline Volcanic assemblage and the Central Anatolian Volcanic Provinces [23]. All of the Turkish borate deposits are classified as volcanic related deposits. The borate deposits in Bigadiç, Sultançayırı (Balıkesir), Kestelek (Bursa), Emet (Kütahya) and Kırka (Eskişehir) were created in the playa-lake sediments during Miocene volcanism. The borate minerals are formed within the sequence consisting of conglomerate, sandstone, claystone, shale, marl, limestone and tuff intercalation [24].

Figures 1 and 2 show that Kurka B deposits area were composed of the lithology from old to young, respectively the Zahrendere Travertine Formation (composed of yellow-white limestone), the Lepçekdere Formation (claystone, limestone, borate in marl), the Salihiye Formation (opal in limestone), the Karaören Formation (clayey tuff, claystone, limestone and opal) and the Kirka Formation (tuff, claystone, limestone, borate and opal) [25].

The Kırka borate deposit (Miocene, Western Turkey), is the most important $\mathrm{B}_{2} \mathrm{O}_{3}$ producer in the world at present. It exhibits a symmetrical zonation in a lateral sense. It is comprised of a central body of Na borate (borax), an intermediate zone of Na-Ca borate (ulexite), and a marginal zone of Ca borate (colemanite). This mineral zonation is also developed in a vertical sense, while it shows an asymmetrical zonation because of the presence of a discontinuous $\mathrm{Mg}$ borate horizon overlying the central body of borax [24].

\section{Materials and Methods}

The natural plant species and representative soil samples were collected from the Boron mining areas especially in Kırka and Bigadiç, Emet borate deposits. The surface soil samples were collected in the depth range of 15 - 20 $\mathrm{cm}$ and stored in plastic bags. The plant species were identified from study [26], and then plant samples were separated into twigs, leaves, spikes and barks.

Digested of Plant Samples: the plant samples were washed with water and than dried in the oven-dried at $80^{\circ} \mathrm{C}$ for $24 \mathrm{~h}$. The $0.20 \mathrm{~g}$ of the dry grounded plant samples were placed into the porcelain crucible and fired up to $550^{\circ} \mathrm{C}$ in the muffle furnace with a heating rate of $50^{\circ} \mathrm{C} / \mathrm{h}$ for $7 \mathrm{~h}$. Then, the ashes were taken and evaporated with $2 \mathrm{ml} 0.1 \mathrm{M} \mathrm{HCl}(1 / 3)$ at $45-50^{\circ} \mathrm{C}$ by using a hot-plate. The residue was dissolved in $25 \mathrm{ml}$ of deio- nized water and filtrated by using filter papers [27,28].

Extraction Boron from Soil Samples: The soil samples were oven-dried at $80^{\circ} \mathrm{C}$ for $10 \mathrm{~h}$ and than were ground and then sieved under 80 mesh. The $5.00 \mathrm{~g}$ of dried soil samples and $20.00 \mathrm{ml}$ of extraction solutions (0.01 M Mannitol + $0.01 \mathrm{M} \mathrm{CaCl}_{2}$ ) were shake for $16 \mathrm{~h}$ into shaker. The mixture was filtrated using filter paper and the boron determinate in soil extract solutions $[27,29,30]$.

Boron Analysis: The B concentrations in the digested plant and soil extract solutions were determined according to the method suggested [27-30]. The $12.5 \mathrm{ml}$ of the extract plant and soil extract solutions were transferred into a $25 \mathrm{ml}$ flask, The $2.5 \mathrm{ml}$ ammonium acetate tampon solution with the $\mathrm{pH}$ of 8 and the $2.5 \mathrm{ml}$ of $0.3 \% 3,4-$ Dihydroxyazomethine- $\mathrm{H}$ solution in $1 \%$ ascorbic acid and the solution completed to $25 \mathrm{ml}$ by deionised water. The solution are mixed and kept for 90 min. in dark and then the absorbance of the solution was measured at 420 $\mathrm{nm}$ by Genesys 20 model Spectrophotometer.

The $20 \mathrm{mg} \cdot \mathrm{ml}^{-1}$ stock standard boron solutions were prepared by dissolving sodium borate. Then, some of these stock solutions with different volume were taken and diluted with distillated water in order to prepare diluted solutions with certain concentrations (from 2 $\mathrm{mg} \cdot \mathrm{ml}^{-1}$ to $8 \mathrm{mg} \cdot \mathrm{ml}^{-1}$ ). The absorbance of these freshly diluted solutions was measured and then the calibration graph was obtained.

The measurements of the water samples taken from waste water pool (in the surface water) in the Kurka and the Emet deposit areas were performed directly.

Other Element Analysis: Determination of $\mathrm{Sr}, \mathrm{Li}, \mathrm{Cu}$, $\mathrm{Zn}, \mathrm{Mn}, \mathrm{Co}$, and $\mathrm{Ni}$ in soil samples were analyzed by Flame Atomic Absorption Spectrophotometer [31].

\section{Results and Discussions}

The plant species such as Gypsophila perfoliata L., Pinus nigra Arn, Chrysopogon gryllus (L.) Trin., Juniperus oxicedrus L. subsp., Juniperus foetidissima Willd., Apera intermedia Hackel, Quercus trojana P.B. Webb, Puccinellia intermedia (Schur) Janchen, Alyssum sibiricum Willd, Genista aucheri Boiss and Euphorbia hirsuta L. are grown widely in Kırka and Emet, Bigadiç borate deposits. A few plant, soil and water samples were taken from Emet and Bigadiç (not water) in order to comparate with Kırka area. The maximum, minimum and the average $B$ values of all plant and soil samples which were taken from these deposits are given in Table 1 for leaves, twigs, spikes and barks.

The B values of soil samples taken from the Kirka borate deposit varies between $1 \mathrm{ppm}$ and $723 \mathrm{ppm}$, while the $B$ values of the soil samples taken from Emet and Bigadiç varies between $1 \mathrm{ppm}$ to $130 \mathrm{ppm}$. The $\mathrm{B}$ values of the natural soil samples are in the range of $0.10-80$ 


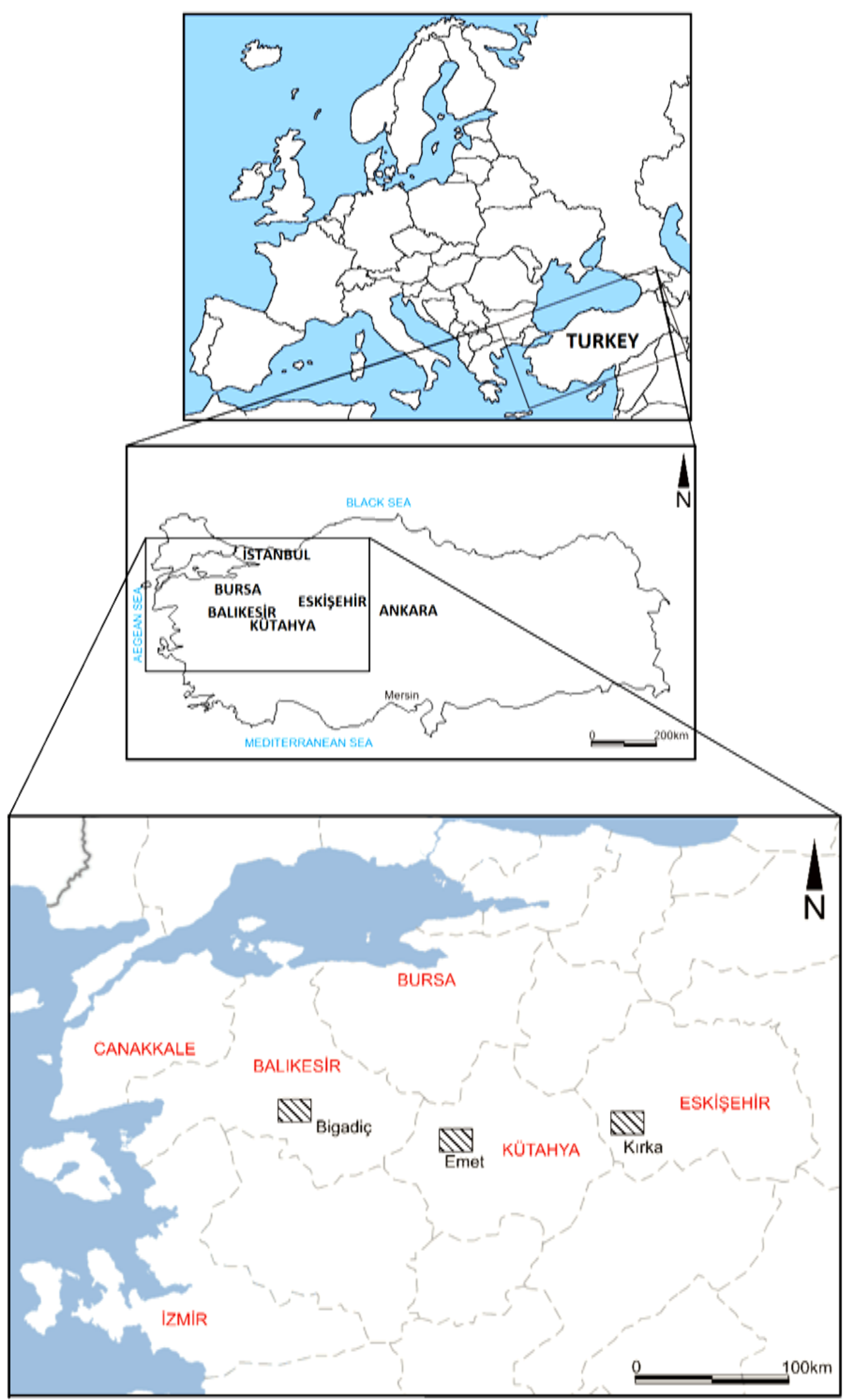

Figure 1. Location map of study area. 


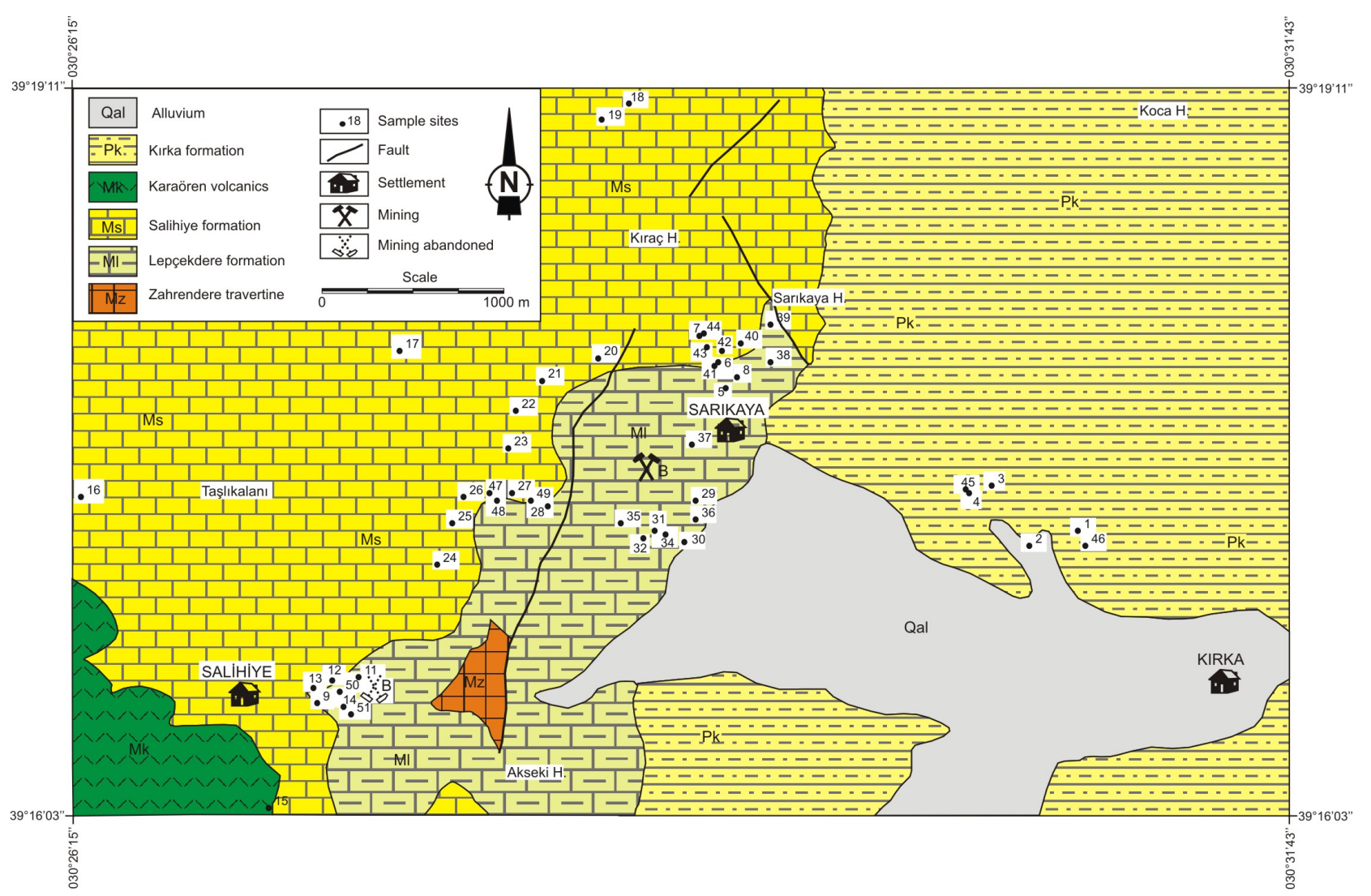

Figure 2. Geological map of the Kırka (Eskişehir) area (simplified from Gök et al., 1979).

Table 1. Boron concentrations in various plants and their organs and in soils from Kurka (Eskişehir) boron deposits.

\begin{tabular}{|c|c|c|c|c|c|c|c|c|}
\hline \multirow{2}{*}{ The plant species } & & \multirow{2}{*}{$\mathrm{n}$} & \multicolumn{3}{|c|}{ B content in the soil $(\mu \mathrm{g} / \mathrm{g})$} & \multicolumn{3}{|c|}{ B content in the plant $(\mu \mathrm{g} / \mathrm{g})$} \\
\hline & & & Min. & Max. & Average & Min. & Max. & Average \\
\hline \multirow{3}{*}{ Alyssum sibiricum Willd } & Twigs & 9 & 5 & 21 & 9 & 38 & 188 & 76 \\
\hline & Leaves & 9 & 5 & 21 & 9 & 50 & 325 & 160 \\
\hline & Twigs & 8 & 1 & 16 & 6 & 31 & 51 & 43 \\
\hline \multirow[t]{2}{*}{ Chrysopogon gryllus (L.) Trin } & Leaves & 9 & 1 & 18 & 7 & 48 & 736 & 181 \\
\hline & Barks & 5 & 3 & 8 & 4 & 33 & 87 & 54 \\
\hline \multirow{3}{*}{ Gypsohila perfoliata L. } & Twigs & 23 & 9 & 723 & 162 & 43 & 243 & 130 \\
\hline & Leaves & 22 & 9 & 723 & 162 & 95 & 1102 & 526 \\
\hline & Twigs & 17 & 8 & 462 & 219 & 36 & 190 & 119 \\
\hline \multirow[t]{2}{*}{ Puccinellia intermedia (Schur) Janchen } & Spikes & 18 & 8 & 462 & 216 & 99 & 641 & 285 \\
\hline & Barks & 19 & 8 & 462 & 216 & 88 & 445 & 255 \\
\hline \multirow{2}{*}{ Quercus trojana PB Webb } & Twigs & 28 & 2 & 15 & 5 & 43 & 119 & 72 \\
\hline & Leaves & 28 & 2 & 15 & 5 & 45 & 423 & 191 \\
\hline \multirow{2}{*}{ Genista aucheri Boiss. } & Twigs & 27 & 1 & 21 & 6 & 39 & 188 & 81 \\
\hline & Leaves & 14 & 1 & 21 & 6 & 71 & 250 & 142 \\
\hline \multirow{2}{*}{ Juniperus Oxycedrus L. Subsp } & Twigs & 27 & 1 & 16 & 5 & 36 & 308 & 77 \\
\hline & Leaves & 28 & 1 & 16 & 5 & 37 & 204 & 89 \\
\hline \multirow{2}{*}{ Pinus nigra Arn. } & Twigs & 24 & 1 & 16 & 5 & 38 & 602 & 180 \\
\hline & Leaves & 16 & 1 & 10 & 4 & 44 & 223 & 115 \\
\hline \multirow{2}{*}{ Juniperus foetidissima Willd } & Twigs & 3 & 5 & 15 & 9 & 78 & 434 & 231 \\
\hline & Leaves & 2 & 6 & 15 & 10 & 63 & 103 & 83 \\
\hline \multirow{2}{*}{ Apera intermedia Hackel } & Twigs & 2 & 321 & 390 & 355 & 850 & 1160 & 1005 \\
\hline & Spikes & 2 & 321 & 390 & 355 & 700 & 1197 & 948 \\
\hline \multirow{2}{*}{ Euphorbia hirsuta L. } & Twigs & 23 & 2 & 15 & 5 & 47 & 115 & 68 \\
\hline & Leaves & 21 & 2 & 15 & 5 & 62 & 220 & 119 \\
\hline
\end{tabular}


ppm [5,21,32,33]. The B values of the three borate deposits are higher than the values of the natural soil samples. Thus, these values can be accepted as anomaly values.

On the other hand, the boron in the water samples of Kirka borate deposits area at 1, 2, 4, 14 and 50 stations are 272 ppm, 326 ppm, 510 ppm, 295 ppm, 195 ppm, respectively (Figures 1 and 2). The boron value of the water samples of Emet borate deposit at one station is 590 ppm. The value of $\mathrm{B}$ is $10 \mathrm{ppb}$ in the natural water [5]. The $\mathrm{B}$ values of the water samples taken from borate deposit areas are higher than the values of the natural water samples, and these values can be accepted anomaly values.

Predominantly, the high B content of the soils is reflected in the parts of the plant species. The $\mathrm{B}$ values of the plant species are ranged from $31 \mathrm{ppm}$ to $1197 \mathrm{ppm}$ and the $\mathrm{B}$ values of the natural plant samples are ranged from $0.1 \mathrm{ppm}$ to $1 \mathrm{ppm}$. However, these values are up to $230 \mathrm{ppm}$ in the contaminated area [5,21,32,33]. The B values of the plant species of the borate deposits region are higher than the natural plant samples. Therefore, these values can be accepted anomaly values.

The $\mathrm{B}$ content of the soil and the plant samples given in Table 1 was plotted. It was observed that the correlation between $\mathrm{B}$ in the part of the plants (G. perfoliata ( $\mathrm{r}$ $<0.413$ for twigs, $\mathrm{r}<0.423$ for leaves), C. gryllus ( $\mathrm{r}<$ 0.707 for twigs, $r<0.666$ for leaves and $r<0.878$ for barks), J. oxicedrus ( $\mathrm{r}<0.380$ for twigs, $\mathrm{r}<0.468$ for leaves), J. foetidissima ( $\mathrm{r}<0.997$ for twigs), Q. trojana $(\mathrm{r}$ $<0.372$ for twigs, $\mathrm{r}<0.372$ for leaves), A. sibiricum $(\mathrm{r}<$ 0.666 for twigs, $\mathrm{r}<0.666$ for leaves) and E. hirsute $(\mathrm{r}<$ 0.413 for twigs, $r<0.433$ for leaves, for $n>3$ ) and soil were not significant at $95 \%(\mathrm{P}>0.05)$ confidence level. Because the slope of the regression (r) line of the experimental is lowest than theoretical regression (r) line. Furtermore, J. foetidissima (for leaves), and A. intermedia (for twigs and leaves) are insufficient samples, for $n$ $<3$.

In contrast to that a statistically significant plant/soil relationship was observed for the B in the twigs of $G$. aucheri, in the twigs of $P$. intermedia, and in the leaves of $P$. nigra and presented in Figures 3-5, respectively. The slope of the regression (r) lines was 0.8581 (for 26 samples), 0.7274 (for 17 samples) and 0.6805 (for 16 samples), respectively. All of the relationships are highly significant (99\% confidence level, $\mathrm{P}<0.01$ ).

The sensitivity of the $P$. nigra, $G$. aucheri and $P$. intermedia plant species is shown in Figure 6. It is clear in Figure 6 that $P$. nigra is the most sensitive and $G$. $a u$ cheri is more sensitive than $P$. intermedia. Therefore, it is better to prefer to start with the most sensitive one for biogeochemical prospecting in the future. Morever, bioconcentration factor (BF, B plant/Bsoil); P. nigra $16.0>$ G. aucheri $6.3>$ P. intermedia 0.9 .

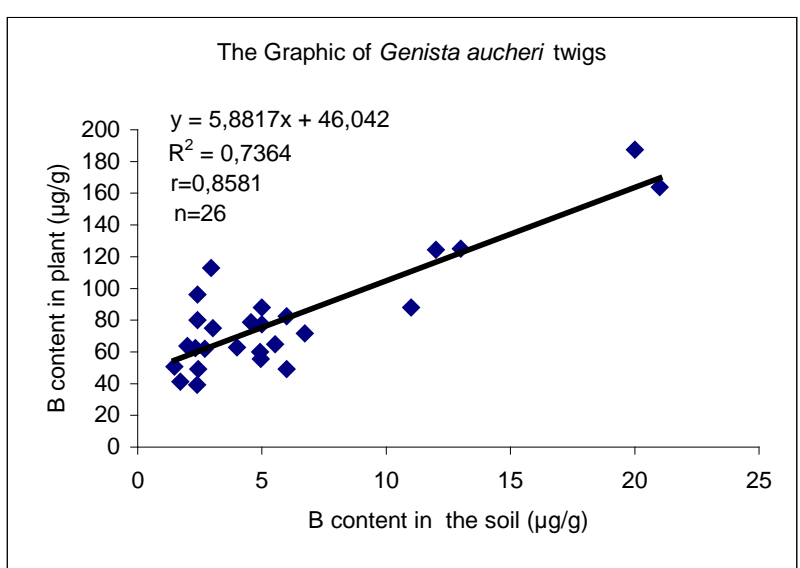

Figure 3. The relationship between the concentration of $\mathbf{B}$ in the soil and $B$ in the Genista aucheri twigs.

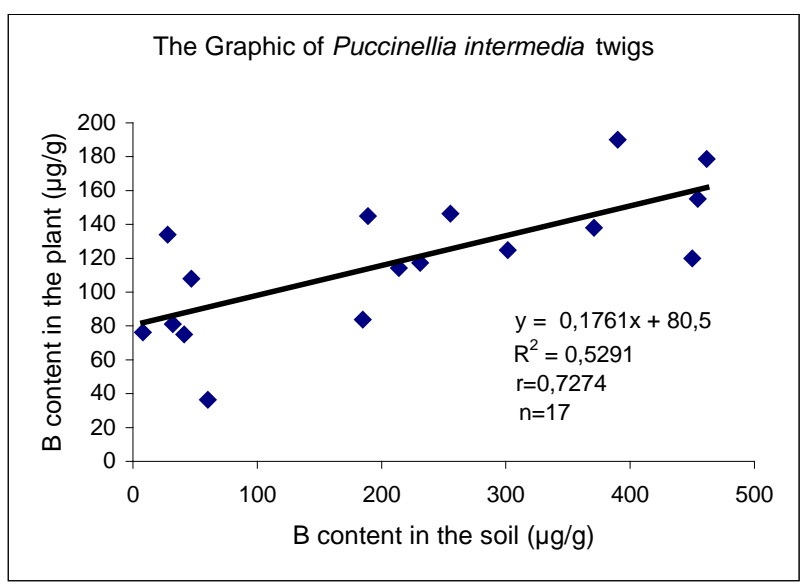

Figure 4. The relationship between the concentration of $\mathbf{B}$ in the soil and B in the Puccinellia intermedia twigs.

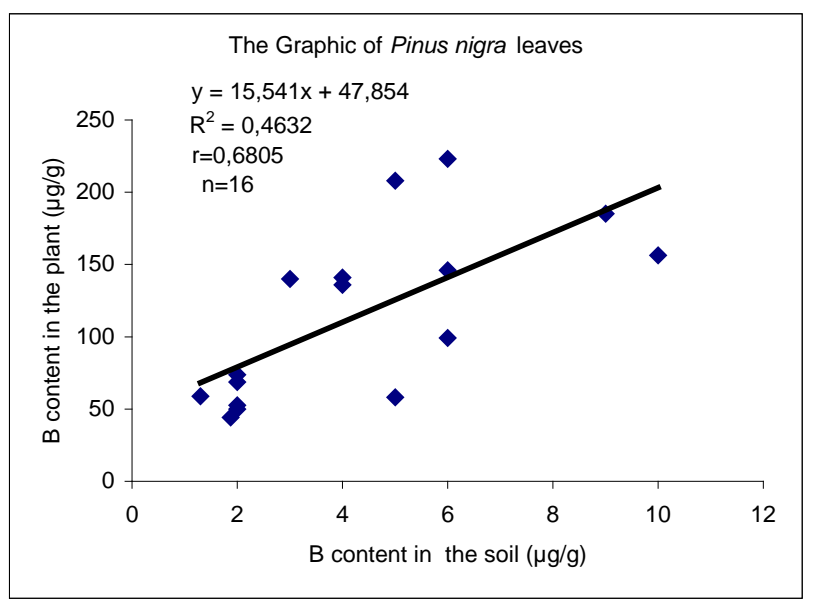

Figure 5. The relationship between the concentration of $\mathbf{B}$ in the soil and $B$ in the Pinus nigra leaves.

The inter-elemental relationship between the $\mathrm{B}$ concentration of the indicator plants and some other elements (B, Sr, Li, Cu, Zn, Mn, Co and $\mathrm{Ni}$ ) of the soil was 


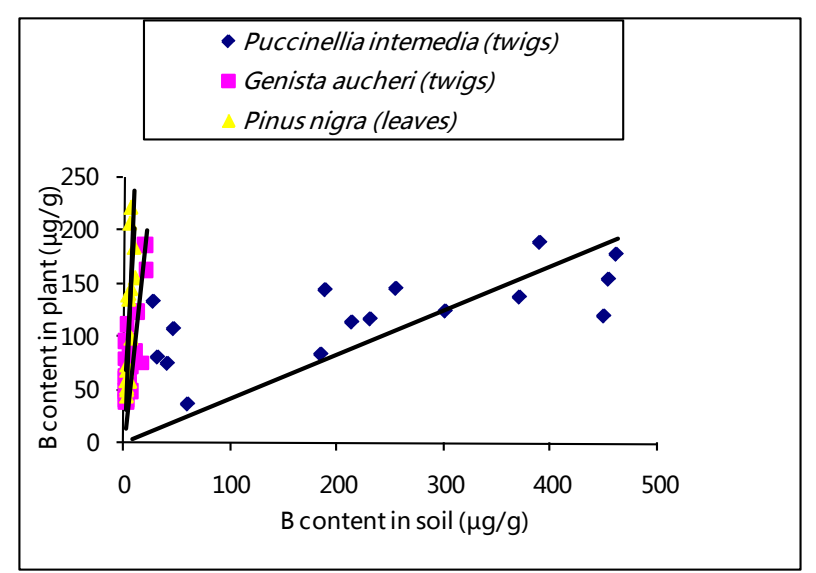

Figure 6. The correlation between the $B$ contents of the Puccinellia intermedia (twigs), Genista aucheri (twigs), Pinus nigra (leaves) and the soil.

shown in Table 2.

As it was seen in Table 2, there was relationships of B concentration in the twigs of $G$. aucheri, in the twigs of $P$. intermedia, in the leaves of P. nigra and the $\mathrm{Sr}, \mathrm{Li}, \mathrm{Cu}$, $\mathrm{Zn}, \mathrm{Mn}, \mathrm{Co}$ and Ni elements in the soil are not significant (95\% confidence level, $\mathrm{P}>0.05$ ). Therefore, $\mathrm{B}$ in the plants has been independent to $\mathrm{Sr}, \mathrm{Li}, \mathrm{Cu}, \mathrm{Zn}, \mathrm{Mn}, \mathrm{Co}$ and $\mathrm{Ni}$ in the soil. In addition, it is obvious that the $\mathrm{B}$ concentration in the indicator plants depends on the $\mathrm{B}$ concentration in the soil.

\section{Conclusions}

In the present study, the elemental contents of the plants (G. perfoliata, P. nigra, C. gryllus, J. oxicedrus, J. foetidissima, A. intermedia, Q. trojana, P. intermedia, A. sibiricum, G. aucheri, E. hirsuta), soil, and water taken mainly from Kırka and also from Emet and Bigadiç borate deposit areas are chemically analyzed. The B concentrations in the samples were compared with the B concentrations of the natural plant, soil and water. It was investigated that the B concentrations of all the samples regardless whether it is plant or soil or water are anomaly. However, it was observed that there was a relation between the B concentration of only the twigs of G. aucheri, the twigs of $\mathrm{P}$. intermedia and the leaves of $P$. nigra plants and the B concentration of the soil (Figures 7(a)-(c), respectively). Therefore, these plant species are determined as indicator plants. Besides, the B concentration of these indicator plants is independent to the concentration of the $\mathrm{Sr}, \mathrm{Li}, \mathrm{Cu}, \mathrm{Zn}, \mathrm{Mn}, \mathrm{Co}$, and Ni elements in the soil. This means that the indicator plant can take B from the soil regardless it has these elements or not.

It is concluded that the B content in the twigs of $G$. aucheri, in the twigs of P. intermedia and in the leaves of $P$. nigra yielded good indications for biogeochemical prospecting and could be successfully used as environ-
Table 2. Results of correlation analysis for inter-elemental relationships between soil and plants.

\begin{tabular}{|c|c|c|c|c|c|c|c|c|c|}
\hline \multirow{2}{*}{\multicolumn{2}{|c|}{$\begin{array}{l}B \text { in the Indicator } \\
\text { plants }\end{array}$}} & \multicolumn{8}{|c|}{ Elements in the soil } \\
\hline & & B & $\mathrm{Sr}$ & $\mathrm{Li}$ & $\mathrm{Cu}$ & $\mathrm{Zn}$ & Mn & Co & $\mathrm{Ni}$ \\
\hline $\begin{array}{c}\text { Puccinellia } \\
\text { intermedia } \\
\text { (Schur) } \\
\text { Janchen }\end{array}$ & Twigs & $\mathrm{S}$ & NS & NS & NS & NS & NS & NS & NS \\
\hline $\begin{array}{c}\text { Genista } \\
\text { aucheri Boiss }\end{array}$ & Twigs & S & NS & NS & NS & NS & NS & NS & NS \\
\hline $\begin{array}{l}\text { Pinus nigra } \\
\text { Arn. }\end{array}$ & Leaves & $\mathrm{S}$ & NS & NS & NS & NS & NS & NS & NS \\
\hline
\end{tabular}

S: highly significant $(p<0.01)$. NS: not significant $(\mathrm{P}>0.05)$.

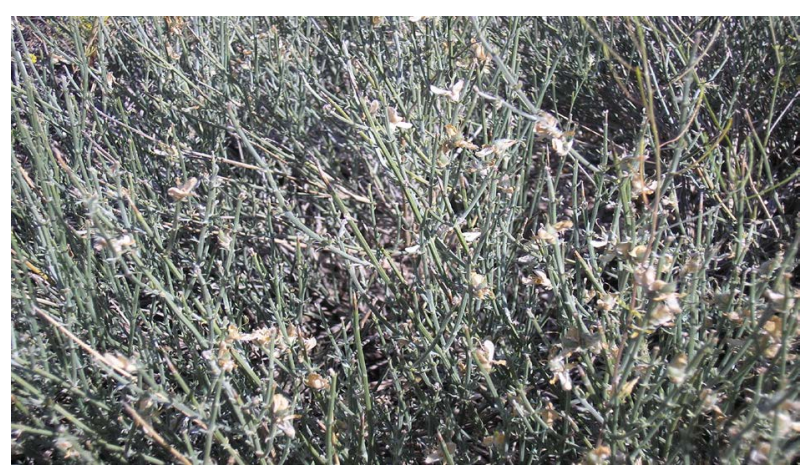

(a)

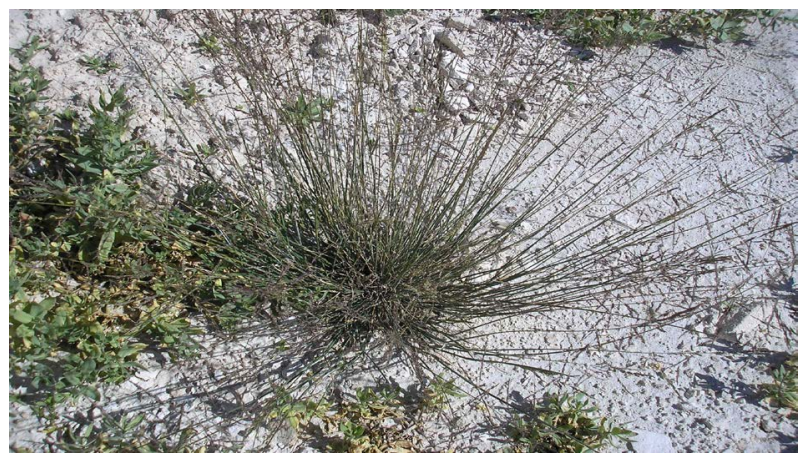

(b)

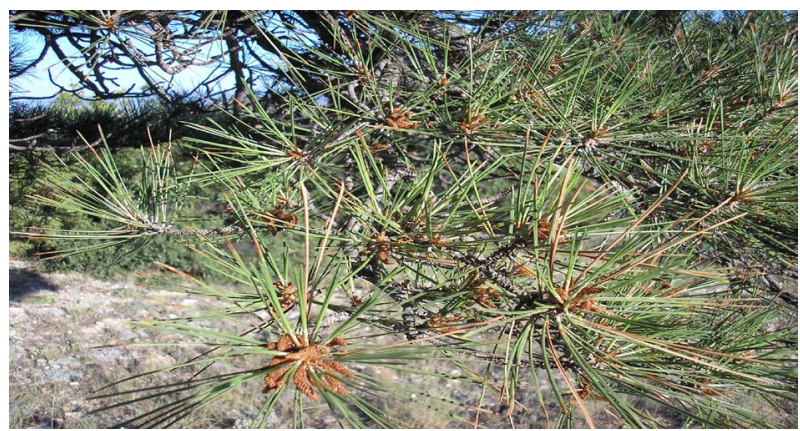

(c)

Figure 7. The photographs of the plant species; (a) Genista aucheri, (b) Puccinellia intermedia, and (c) Pinus nigra.

mental monitor for environmental pollution studies. 


\section{Acknowledgements}

The TÜBITAK is acknowledged for financial support (project number is 104Y009). The authors would like to thank Prof. Dr. B. Y1ldı (Balıkesir University, Turkey) and Assist. Prof. Dr. R. Binzet (Adiyaman University, Turkey) for determination of the plant sample names and Dr. S. Erat (ETH-Zurich, Switzerland) for helpful technical discussions.

\section{REFERENCES}

[1] C. Helvaci and F. Orti, "Zoning in the Kurka Borate Deposit, Western Turkey: Primary Evaporitic Fractionation or Diagenetic Modifications?” The Canadian Minerologist, Vol. 42, No. 4, 2004, pp. 1179-1204.

http://dx.doi.org/10.2113/gscanmin.42.4.1179

[2] N. Arslan, A. Çiçek and C. Akkan, “Accumulation of Heavy Metals by Earthworms in Boron-Contaminated Area (Kırka-Eskișehir)," Zoology in the Middle East, Vol. 51, Suppl. 2, 2010, pp. 111-116. http://dx.doi.org/10.1080/09397140.2010.10638463

[3] M. Köksoy, “Uygulamalı Jeokimya,” Hacettepe University Publication, Ankara, 1991, p. 366 [in Turkish].

[4] R. R. Brooks, C. E. Dunn and G. E. M. Hall, "Biological System in Mineral Exploration and Processing," Elles Horwood Limitid, Bel Air, 1995, p. 538.

[5] A. W. Rose, H. E. Hawkes and J. S. Webb, "Geochemistry in mineral Exploration,” 2nd Edition, Academic Press, New York, 1979, p. 657.

[6] A. L. Kovalevskii, "Biogeochemical Prospecting for Ore Deposits in the U.S.S.R, Journal of Geochemical," $E x$ ploration, Vol. 21, No. 1-3, 1984, pp. 63-72.

[7] A. Sağiroğlu and Z. Özdemir, "Biogeochemical Prospection,” Geological Engineering, Vol. 51, 1997, pp. 1-17.

[8] P. A. Floyd, C. Helvaci and S. K. Mittwede, "Geochemical Discrimination of Volkanic Rocks Associated with Borate Deposits: An Exploration Tool?” Journal of Geochemical Exploration, Vol. 260, No. 3, 1998, pp. 185205.

[9] Z. Özdemir, "Biogeochemical Studies at the Musalı and Silifke-Anamur Area in Mersin, Turkey,” Geochemistry International, Vol. 241, No. 9, 2003, pp. 1-6.

[10] Z. Özdemir, "Pinus brutia as a Biogeochemical Medium to Detect İron and Zinc in Soil Analysis, Cromite Deposits of the Area Mersin, Turkey," Chemie der Erde, Vol. 265, No. 1, 2005, pp. 79-88.

[11] M. Babaoğlu, S. Gezgin, B. Sade and H. Dural, “Gypsophila sphaerocephala Fezl ex Tchihat.: A. Boron Hyperaccumulator Plant Species That May Phytoremediate Soils with Toxic B Levels, TUBITAK,” Turkish Journal of Botany, Vol. 28, No. 3, 2004, pp. 273-278.

[12] W. H. Schlesınger, "Biogeochemistry,” In: H. D. Holland and K. K. Turekian, Eds., Treatise on Geochemistry, 8th Edition, Elsevier, London, 2006, p. 702,

[13] H. Turan, Z. Özdemir and S. Zorlu, "İnvestigation of Biogeochemical Anomalies for $\mathrm{Cu}, \mathrm{Zn}, \mathrm{Fe}, \mathrm{Mn}$, and $\mathrm{Ni}$ in
Çiftehan (Ulukışla-Niğde) Area,” Istanbul Earth Science Review, Vol. 219, No. 2, 2006, 131-140 [in Turkish with English Abstract].

[14] M. J. Batista, M. M. Abreu and P. M. Serrano, "Biogeochemistry in Neves Corvo Mining Region, Iberian Pyrite Belt, Portugal," Journal of Geochemical Exploration, Vol. 292, No. 2-3, 2007, pp. 159-176.

[15] C. E. Dunn, "Biogeochemistry in Mineral Exploration," Handbook of Exploration and Environmental Geochemistry, Vol. 9, Elsevier, London, 2007, p. 462.

[16] E. Demir and Z. Özdemir, "Kazanlı (Mersin) Bölgesinde $\mathrm{Cr}, \mathrm{Fe}$, Ni ve Co Nun Çevreye Etkisi ve bir Biyojeokimyasal Çalışma,” Mersin Symposium, Mersin, 19-22 November 2008, pp. 146-159 [in Turkish],

[17] T. Unver, O. Bozkurt and M. S. Akkaya, "Identification of Differentially Expressed Transcripts from Leaves of the Boron Tolernt Plant Gypsophila perfoliata L.," Plant Cell Reports, Vol. 227, No. 8, 2008, pp. 1411-1422.

[18] Z. Özdemir, "Bitkilerle Maden Bulunabilir Mi? Biyojeokimyasal (Bitki Jeokimyası) Prospeksiyon Nedir?” Journal of Mining and Earth Science, Vol. 21, No. 3, 2009, pp. 14-19 [in Turkish].

[19] Z. Özdemir and E. Demir, "Nickel Accumlating Species of Alyssum murale Waldst. \& Kit from Findıkpınar1-Erdemli/Mersin Area," Geology Engineering, Vol. 234, No. 1, 2010, pp. 57-70 [in Turkish with English abstract].

[20] A. R. Stiles, D. Bautista, E. Atalay, M. Babaoğlu and N. Terry, "Mechanisms of Boron Tolerance and Accumulation in Plants: A Physiological Comparison of the Extremely Boron-Tolerant Plant Species, Puccinellia distans, with the moderately Boron-Tolerant Gysophila arrostil," Environmental Science \& Technology, Vol. 244, No. 18, 2010, pp. 7089-7095. http://dx.doi.org/10.1021/es1016334

[21] W. Bergman, "Nutritional Disorders of Plants, Development, Visual and Analytical Diagnosis," Gustav Fischer Verlag, Jena, 1992, p. 741.

[22] R. O. Nable, G. S. Banuelos and J. G. Paull, "Boron Toxicity,” Plant and Soil, Vol. 2193, No. 1-2, 1992, pp. 181198. http://dx.doi.org/10.1023/A:1004272227886

[23] Y. Savaşçin and T. Oyman, “Tectono-Magmatic Evolution of Alkaline Volcanis at the Kirka-Afyon-Isparta Structural Trend, SW Turkey," Turkish Journal of Earth Sciences, Vol. 27, 1997, pp. 201-214 [in Turkish].

[24] C. Helvac1, "The Geological Situation and Economical Importance of Turkey Borate Deposits and Borate Policy. 5," Symposium of Industrial Minerals, İzmir, 2004, pp. 11-27 [in Turkish with English Abstract].

[25] S. Gök, A. Çakir and A. Dündar, "Survey of Kırka Towns and Surrounding Area Borate Deposits and other Industrial Minerals,” Mineral Research and Exploration Institute of Turkey (MTA) Report No: 6768 [Unpublished, in Turkish with English Abstract], 1979.

[26] P. H. Davis, "Flora of Turkey and the East Aegean Islands,” Vol. 1-9, Universty Press, Edinburgh, pp. 19651985.

[27] A. Alkan, "Resistance of Different Cereal Species and Wheat and Barley Cultivars to Boron Toxicity and Fac- 
tors Affecting Expression of High Boron Resistance," PhD Thesis, Çukurova University, Adana, [Unpublished, in Turkish with English Abstract], 1998.

[28] L. Zaijun, C. Zhengwei and T. Jian, "The Determination of Boron in Food and Seed by Spectrophotometry Using a New Reagent 3,4-Dihydroxyazomethine-H," Food Chemistry, Vol. 294, No. 2, 2006, pp. 310-314. http://dx.doi.org/10.1016/j.foodchem.2005.01.019

[29] L. R. Spouncer, R. O. Nable and B. Cartwright, “A Procedure for the Determination of Soluble Boron in Soils Ranging Widely in Boron Concentrations, Sodicity and $\mathrm{pH}$," Communications in Soil Science and Plant Analysis, Vol. 223, No. 5-6, 1992, pp. 441-453
[30] F. T. Bingham, “Boron,” In: A. L. Page, R. H. Miller and D. R. Keeney, Eds., Methods of Soil Analysis, Part 2, Madison, 1982, pp. 431-447.

[31] R. R. Brooks, A. J. M. Baker and F. Malaisse, "Copper Flowers," National Geographic Research and Exploration, Vol. 8, 1992, pp. 338-351.

[32] H. Özbek, Z. Kaya, M. Gök and H. Kaptan, “Toprak Bilimi, Çukurova,” University Publication 73, 1993, p. 816 [in Turkish],

[33] B. Kacar and A. V. Katkat, "Bitki Besleme," 4th Edition, Nobel Publication, No. 849, Ankara, 2009, p. 657 [in Turkish]. 